\title{
Opioid Receptors Modulate Diverse Types of Calcium Channels in the Nucleus Tractus Solitarius of the Rat
}

\author{
Hyewhon Rhim and Richard J. Miller \\ Department of Pharmacological and Physiological Sciences, The University of Chicago, Chicago, Illinois 60637
}

\begin{abstract}
We have investigated the coupling between opioid receptors and different types of $\mathrm{Ca}^{2+}$ channels in neurons acutely isolated from the nucleus tractus solitarius (NTS) of the rat. Using fura-2-based imaging we found that $\mathrm{Ca}^{2+}$ transients evoked by depolarization with $50 \mathrm{~mm} \mathrm{KCl}$ were suppressed by the $\mu$-opioid receptor agonist D-Ala ${ }^{2}, \mathrm{~N}$-MePhe ${ }^{4}, \mathrm{Gly}^{5}$-ol-enkephalin (DAMGO) and less effectively by the $k$-receptor agonist U-69,593. The $\delta$-receptor agonist D-Pen ${ }^{2}, \mathrm{D}-\mathrm{Pen}^{5}$-enkephalin (DPDPE) was ineffective. In whole-cell voltage-clamp recordings from these neurons, depolarizing voltage steps elicited high-threshold $\mathrm{Ca}^{2+}$ currents that could be distinguished pharmacologically into different components. Part of the current could be blocked by dihydropyridines, part by $\omega$-conotoxin-GVIA and part by $\omega$-agatoxin-IVA. This suggests that the neurons contained $\mathrm{L}-, \mathrm{N}$-, and $\mathrm{P} / \mathrm{Q}$-type $\mathrm{Ca}^{2+}$ channels. DAMGO and $\mathrm{U}-69,593$ both blocked part of the $\mathrm{Ca}^{2+}$ current but DPDPE was ineffective. Perfusion of GTP- $\gamma-S$ into the cells produced a rapid rundown of the $\mathrm{Ca}^{2+}$ current and occluded further effects of the opioid agonists, suggesting the involvement of a G-protein in the coupling mechanism. Inhibition of L-channels did not alter the effect of DAMGO. On the other hand inhibition of $\mathrm{N}$-channels occluded about $80 \%$ of the effect of DAMGO. Inhibition of the P/Q-current occluded the remainder of the DAMGO effect. Thus, it appears that activation of opioid receptors can inhibit $\mathbf{N}$ - and $\mathrm{P} / \mathrm{Q}$-type $\mathrm{Ca}^{2+}$ channels but not L-channels in these cells. It is likely that such effects are important in opioid-mediated inhibition of transmitter release in the brain.
\end{abstract}

[Key words: enkephalin, autonomic nervous system, $\mu-0-$ pioid receptor, w-conotoxin-GVIA, dihydropyridine, w-agatoxin-[VA]

Endogenous opioids and opioid drugs produce many effects on the nervous system by interacting with a widely distributed receptor system. Receptors for $\mu-, \delta$-, and $\kappa$-selective opioids show a unique distribution in the brain (Reisine and Bell, 1993). Activation of these receptors produces a number of effects on neurons at both pre- and postsynaptic sites (North, 1993a,b).

\footnotetext{
Received Mar. 7, 1994; revised June 2, 1994; accepted June 8, 1994.

We thank Dr. Vytautas Bindokas for helping with imaging experiments and Dr. Peter Toth for helping with the initial electrophysiology studies. This work was supported by National Institute on Drug Abuse Grant DA-07255 to H.R., by the Brain Research Foundation, by Digestive Care Center Award 1P30DK42086-01, and by U.S. Public Health Service Grants DA-02575, DA-02121, and MH-40165 to R.J.M.

Correspondence should be addressed to Richard J. Miller, Ph.D., Department of Pharmacological and Physiological Sciences, The University of Chicago, 947 East 58th Street, Chicago, IL 60637.

Copyright $(1) 1994$ Society for Neuroscience $0270-6474 / 94 / 147608-08 \$ 05.00 / 0$
}

For example, opioids have often been observed to hyperpolarize neurons due to the activation of a $\mathrm{K}^{+}$conductance (North, 1993a). A second widely reported effect of opioids is their ability to inhibit the release of neurotransmitters in both the central and peripheral nervous systems (North, 1993b). Indeed, this latter effect formed the basis of most of the classical bioassays for opioid agonist activity. How are opioids able to do this? Three major possibilities have been suggested. Stimulation of presynaptic opioid receptors may activate a $\mathrm{K}^{+}$conductance, thereby hindering the movement of action potentials into the presynaptic terminal (North, 1993a). Second, opioids may block $\mathrm{Ca}^{2+}$ influx directly by inhibiting the $\mathrm{Ca}^{2+}$ channels that mediate $\mathrm{Ca}^{2+}$ influx into the nerve terminal (Kennedy and Henderson 1991; Seward et al., 1991; North, 1993a,b). Finally, activation of opioid receptors may produce direct effects on the intracellular machinery that regulates transmitter vesicle exocytosis (Capogna et al., 1993; Rekling, 1993).

It has been demonstrated that several different types of $\mathrm{Ca}^{2+}$ channels exist in neurons (Snutch and Reiner, 1992; Miller, 1993; Zhang et al., 1993). From the functional point of view $\mathrm{Ca}^{2+}$ channels have been classed into "high" and "low" threshold on the basis of the voltage range at which they are activated. Low-threshold $\mathrm{Ca}^{2+}$ channels have also become known as T-type and exhibit a unique pharmacological profile (Herrington and Lingle, 1992). On the other hand, high-threshold $\mathrm{Ca}^{2+}$ currents can be grouped into various classes according to their sensitivities to dihydropyridines (L-type), $\omega$-conotoxin-GVIA ( $\omega$-CgTxGVIA, N-type), $\omega$-agatoxin-IVA ( $\omega$-Aga-IVA, P-or Q-type) or none of these, for example, the R-type currents of cerebellar granule cells. We also know that these activities result from the expression of a family of related $\mathrm{Ca}^{2+}$ channel molecules that exist as multisubunit complexes. Neurotransmitter secretion seems to be preferentially coupled to one or more of these channel types under different circumstances (Luebke et al., 1993; Takahashi and Momiyama, 1993; Toth et al., 1993).

Which of these $\mathrm{Ca}^{2+}$ channels are regulated by opioid receptors? In the PNS there is evidence that all three types of opioid receptors can influence $\omega$-CgTx-GVIA-sensitive N-type channels and it is this type of $\mathrm{Ca}^{2+}$ channel that primarily regulates transmitter release from many peripheral neurons (Lipscombe et al., 1989; Toth et al., 1993). However, nothing is known about the regulation of $\mathrm{Ca}^{2+}$ channels by opioid receptors in the CNS where the relationship between $\mathrm{Ca}^{2+}$ channel type and transmitter release appears to be more complex (Luebke et al., 1993; Takahashi and Momiyama, 1993). We have therefore examined the situation in the nucleus of the solitary tract (NTS), an area of the brain in which opioids are thought to produce many important effects on the activity of the autonomic nervous system (Van Giersbergen et al., 1992). Our results show that opioid 
receptors can influence the activity of both $\mathrm{N}$ - and $\mathrm{P} / \mathrm{Q}-$ type $\mathrm{Ca}^{2+}$ channels, the major types of $\mathrm{Ca}^{2+}$ channels thought to be involved in the regulation of transmitter release in the brain.

\section{Materials and Methods}

Cell preparation. NTS neurons were isolated using a technique modified from Nakagawa et al. (Nakagawa et al., 1990). Transverse slices (400 $\mu \mathrm{m}$ thick) were prepared from the brainstem of Sprague-Dawley rats (7-21 d old) and placed in a holding chamber filled with $32^{\circ} \mathrm{C}$ artificial cerebrospinal fluid (aCSF) containing $126 \mathrm{~mm} \mathrm{NaCl}, 26.2 \mathrm{mM} \mathrm{NaHCO}_{3}$, $1 \mathrm{mM} \mathrm{NaH} \mathrm{PO}_{4}, 3 \mathrm{mM} \mathrm{KCl}, 1.5 \mathrm{mM} \mathrm{MgSO}, 1.5 \mathrm{mM} \mathrm{CaCl}_{2}$, and 10 mM glucose gassed with $95 \% \mathrm{O}_{2}, 5 \% \mathrm{CO}_{2}$. Slices were transferred to a conical tube containing gently bubbled aCSF at $32^{\circ} \mathrm{C}$ to which $1.8 \mathrm{U} / \mathrm{ml}$ dispase (grade I; $0.75 \mathrm{ml} / \mathrm{slice}$ ) was added. After $60 \mathrm{~min}$ incubation, slices were rinsed with enzyme-free aCSF and transferred for storage to a holding chamber with continuously bubbled aCSF at room temperature. When needed, a slice was removed from the chamber and placed on Sylgard-coated petri dish. Under a dissecting microscope, the NTS region was micropunched and placed on poly-L-lysine-coated coverslip. The cells were then dissociated by trituration in saline solution containing $146 \mathrm{~mm} \mathrm{NaCl}, 3 \mathrm{~mm} \mathrm{KCl}, 2 \mathrm{~mm} \mathrm{CaCl}, 1 \mathrm{~mm} \mathrm{MgCl}, 10 \mathrm{~mm}$ HEPES, and $10 \mathrm{~mm}$ glucose $(\mathrm{pH} 7.4)$ using progressively smaller diameter pipettes and allowed to settle on a coverslip for $10 \mathrm{~min}$.

Intracellular $\mathrm{Ca}^{2+}$ imaging. The acetoxymethyl-ester form of fura-2 (fura-2/AM; Molecular Probes, Eugene, OR) was used as the fluorescent $\mathrm{Ca}^{2+}$ indicator. The cells were loaded with fura-2/AM $(5 \mu \mathrm{M})$ for 20 $\mathrm{min}$ at room temperature $10 \mathrm{~min}$ after cells were placed on the coverslips. Cells were rinsed and allowed $20 \mathrm{~min}$ to de-esterify the dye. Intracellular free calcium concentration, $\left[\mathrm{Ca}^{2+}\right]_{i}$, in the neurons was calculated by digital video microfluorimetry using an intensified CCD camera (Hamamatsu) coupled to a microscope (40 $\times$ Fluor objective; Nikon Diaphot) and software (Universal Imaging) on a 486 computer. Cells were illuminated using a $150 \mathrm{~W}$ xenon arc lamp and cxcitation wavelengths ( 340 and $380 \mathrm{~nm}$ ) were selected by a filter changer (Metaltek). Saline with $50 \mathrm{~mm} \mathrm{KCl}\left(50 \mathrm{~K}^{+}\right)$was made with replacing an equivalent amount of $\mathrm{NaCl}$ and applied by a fast $U$-tube perfusion system controlled by timer ( $5 \mathrm{sec}$ duration). Data was expressed as mean \pm SEM for the number of cells responding to an opioid agonist $(>10 \%)$. Cells not responding were not included in this value.

Electrophysiological recordings. Whole-cell voltage-clamp recordings were used (Hamill et al., 1981). Patch electrodes with resistance of 2.5$5 \mathrm{M} \Omega$ were filled with the internal solution containing $140 \mathrm{~mm} \mathrm{CsCl}, 1$ $\mathrm{mm} \mathrm{MgCl}_{2}, 10 \mathrm{~mm}$ BAPTA, $3.6 \mathrm{~mm} \mathrm{Mg-ATP,} 14$ mм Tris creatine phosphate, $0.1 \mathrm{~mm}$ GTP-Tris, and $50 \mathrm{U} / \mathrm{ml}$ creatine phosphokinase, $\mathrm{pH}$ adjusted to 7.4 with $\mathrm{CsOH}$. The external solution contained $10 \mathrm{~mm}$ $\mathrm{BaCl}_{2}, 150 \mathrm{~mm}$ tetraethylammonium (TEA) chloride, $1 \mathrm{mM} \mathrm{MgCl}, 10$ mM HEPES, and $10 \mathrm{~mm}$ glucosc, pH 7.4 with TEA-OH. Current rccordings were obtained using an Axopatch-1D amplifier (Axon Instruments) and filtered at $2 \mathrm{kHz}$. Ca ${ }^{2+}$ currents were evoked every $15 \mathrm{sec}$ by a $200 \mathrm{msec}$ voltage step from $-80 \mathrm{mV}$ to $0 \mathrm{mV}$. Leak currents were subtracted from the data sweeps by scaling the leak sweep to the data. All data were expressed as the mean \pm SEM.

Materials. Dispase (grade I) was purchased from Boehringer Mannheim Co. (Indianapolis, IN). D-Ala ${ }^{2}, N-\mathrm{MePhe}^{4}, \mathrm{Gly}^{5}$-ol-enkephalin (DAMGO), D-Pen ${ }^{2}, \mathrm{D}-\mathrm{Pen}^{5}$-enkephalin (DPDPE), and dynorphin A were from Bachem (Torrance, CA). (+)U-69,593 and nor-binaltorphimine (nor-BNI) were from Research Biochemicals International (Natick, MA). D-Phe-Cys-Tyr-D-Trp-Orn-Thr-Pen-Thr- $\mathrm{NH}_{2}$ (CTOP) and $\omega$-conotoxin-GVIA were from Peninsula Laboratories Inc. (Belmont, CA). $\omega$-Agatoxin-IVA was from Peptides International (Japan). Nimodipine was from Miles laboratories (West Haven, CT). Naloxone, Mg-ATP, di(Tris)-phosphocreatine, creatine phosphokinase, GTP-Tris, and GTP$\gamma$-S were from Sigma (St. Louis, MO). Stock solutions of agonists and antagonists were prepared in purified water. Exception to this was U-69,593, which was dissolved in absolute ethanol. All drugs were applied in the perfusate. Stock solutions of toxins were dissolved in purified water and kept at $-20^{\circ} \mathrm{C}$ until used. Final concentrations were made in recording solution containing $0.1 \mathrm{mg} / \mathrm{ml}$ ovalbumin (Sigma grade $\mathrm{V}$ ) as a carrier protein. Toxins were applied by adding 1 or $2 \mathrm{ml}$ of solution at its final concentration directly to the sample chamber $(0.5$ $\mathrm{ml}$ total volume) and stopping flow for $1.5-2.0 \mathrm{~min}$. Data were still collected during this period. Flow was then resumed. Nimodipine was dissolved in DMSO, diluted in recording solution, and applied by means of the perfusion system.

\section{Results}

\section{Acute isolation of NTS neurons}

NTS neurons were acutely isolated from brainstem slices cut at the level of obex and for several hundred micrometers caudally (see Fig. $1 A$ ). The NTS is a heterogeneous cell group that contains a variety of neuronal types with respect to their anatomic (cell size, shape, and packing density), electrophysiological and neurochemical characteristics. It was recently suggested that 10 subdivisions of the NTS could be distinguished in rats (Van Giersbergen et al., 1992). The area of the NTS used in these experiments included mainly the medial portion plus some of the gelatinosa, dorsal, commissural, and intermediate parts. These areas are believed to be involved in the regulation of the cardiovascular and gastrointestinal systems. The majority of the cell somata obtained were round or oval shaped and measured $12-18 \mu \mathrm{m}$ in diameter (Fig. $1 B$ ), thus corresponding in sizc and shape reported in previous studies (Herbert et al., 1990). Some dissociated cells maintained a few of their original morphological features such as dendritic processes. However, cells without processes were chosen for electrophysiological recordings in order to maintain good space clamp control.

\section{Modulation of evoked calcium signals by opioids}

Increases in $\left[\mathrm{Ca}^{2+}\right]_{i}$ evoked by depolarization were first measured using fura-2-based microfluorimetry. Depolarization using a $5 \mathrm{sec}$ exposure to $50 \mathrm{~K}^{+}$increased $\left[\mathrm{Ca}^{2+}\right]_{i}$ from a resting level of $41.3 \pm 2.1 \mathrm{~nm}$ to a peak level of $824.7 \pm 54.5 \mathrm{~nm}(n$ $=79$ ). Figure $2 A$ shows that the $\mu$-selective receptor agonist DAMGO $(1 \mu \mathrm{M})$ suppressed the $50 \mathrm{~K}+$-induced increase in $\left[\mathrm{Ca}^{2+}\right]_{i}$ by $33.5 \pm 3.8 \%(n=29$ cells responding to DAMGO of 79 tested). The $\kappa$-selective agonist $\mathrm{U}-69,593(1 \mu \mathrm{M})$ also produced inhibition but it was less effective $(15.7 \pm 3.4 \%, n=3$ cells responding to U-69,593 of 15 tested). However, the selective $\delta$-receptor agonist, DPDPE $(1 \mu \mathrm{M})$, had no significant effect in 15 tested cells. The DAMGO-mediated inhibition was completely prevented by simultaneous treatment with the nonselective opioid receptor antagonist naloxone $(10 \mu \mathbf{M}, n=4)$ and recovery from this block was observed after about a $5 \mathrm{~min}$ washout. The inhibition produced by DAMGO was dose related between $1 \mathrm{~nm}$ and $10 \mu \mathrm{M}$ (Fig. 2B).

\section{Inhibition of high-threshold $\mathrm{Ca}^{2+}$ currents by $\mu$-opioids}

These results suggested that both $\mu$-and $\kappa$-agonists could block $\mathrm{Ca}^{2+}$ currents in these neurons. We therefore went on to test this proposal using electrophysiological methods. Whole-cell currents were recorded using $\mathrm{Ba}^{2+}$ as the charge carrier, and $\mathrm{Cs}^{+}$ and TEA as the predominant internal and external cations, respectively. Figure 3.4 illustrates the effect of $\mu$-selective opioid agonist DAMGO on the $\mathrm{Ba}^{2+}$ current through high-threshold $\mathrm{Ca}^{2+}$ channels in one acutely isolated NTS neuron. Application of $1 \mu \mathrm{M}$ DAMGO caused a $51 \%$ inhibition of the peak inward $\mathrm{Ba}^{2+}$ current $\left(I_{\mathrm{Ba}^{2+}}\right)$ that returned to control levels after washout of the agonist (Fig. $3 A$ ). In 49 cells of 92 tested, $1 \mu \mathrm{M}$ DAMGO reduced $I_{\mathrm{Ba}^{2+}}$ by $41.8 \pm 2.2 \%$. In a separate set of experiments we observed that $I_{\mathrm{Ba}^{2}+}$ decreased by $49.0 \pm 3.1 \%$ upon a second exposure to DAMGO within 2 min of the first exposure (46.7 $\pm 3.5 \%$ inhibition produced by the first exposure, $n=10$ ). Thus, the inhibition of $I_{\mathrm{Ba}^{2}+}$ did not desensitize. Curiously, in some cells, DAMGO $(1 \mu \mathrm{M})$ actually produced an increase in the size of $I_{\mathrm{Ba}^{2+}}(17.5 \pm 2.5 \%, n=14$ of 92$)$. However, we did not characterize this response further. 

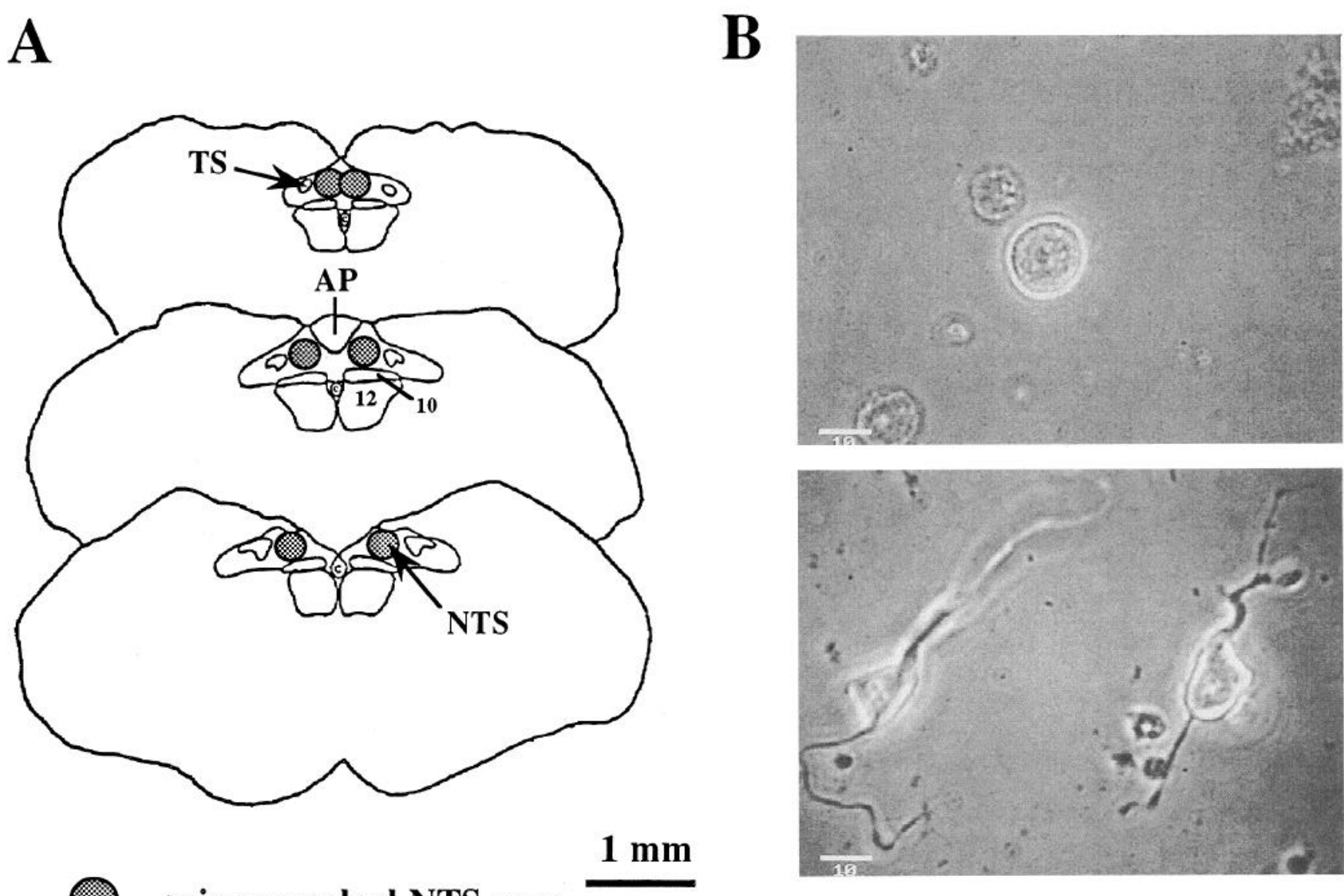

\section{micropunched NTS area}

Figure 1. Location and morphology of acutely isolated nucleus tractus solitarius (NTS) neurons. $A$, NTS neurons were isolated from the shaded areas indicated. $A P$, area postrema; $T S$, solitary tract; $c$, central subnucleus; 10 , dorsal motor vagal nucleus; 12 , hypoglossal nucleus. $B$, Examples of neurons freshly dissociated from an 8-d-old rat. Phase-contrast optics. Scale bars: $A, 1 \mathrm{~mm} ; B, 10 \mu \mathrm{m}$.

Figure $3 B$ illustrates $I_{\mathrm{Ba}^{2}+}$ plotted during multiple exposures to DAMGO in the presence of nonselective opioid antagonist naloxone. The DAMGO-mediated inhibition of $I_{\mathrm{Ba}^{2+}}$ was attenuated by treatment with $1 \mu \mathrm{M}$ naloxone $(42.7 \pm 4.5 \%$ inhibition observed with 1-3 $\mu \mathrm{M}$ DAMGO vs $17.0 \pm 5.8 \%$ in the presence of naloxone, $n=5$ ). The response to the agonist recovered from the block following washout. Figure $3 C$ shows the dose/response relationship for DAMGO inhibition of the current. Figure $3 D$ illustrates the peak current-voltage $(I-V)$ relation for a neuron in the absence and presence of $1 \mu \mathrm{M}$ DAMGO $(n=5)$.

\section{Receptor identification}

As also suggested by the fura- 2 microfluorimetry experiments, the $\kappa$-receptor agonist U-69,593 also inhibited high-threshold $\mathrm{Ca}^{2+}$ channel currents in some acutely isolated NTS neurons. Figure $4 A$ illustrates $I_{\mathrm{Ba}^{2+}}$ inhibition produced by $\kappa$-receptor agonists as well as DAMGO. In this particular cell, the application of nonselective $\kappa$-agonist, dynorphin A, produced $42 \%$ and $56 \%$ inhibition of $I_{\mathrm{Ba}^{2+}}$ at $30 \mathrm{nM}$ and $100 \mathrm{nM}$, respectively. In the same cell the selective $\kappa$-agonist U-69,593 caused a $62 \%$ inhibition of $I_{\mathrm{Ba}^{2+}}$ at $1 \mu \mathrm{M}$. More typically, however, the pattern of inhibition produced by $\mu-, \delta-$, and $\kappa$-selective opioid agonists was as illustrated in Figure $4 B$, in that $\kappa$-agonists were less effective than $\mu$-agonists; $1 \mu \mathrm{M}$ U-69,593 produced a mean re- duction in $I_{\mathrm{Ba}^{2}+}$ of $21.9 \pm 3.5 \%$ in 18 cells from 31 tested. The $\delta$-receptor agonist DPDPE $(1 \mu \mathrm{M})$ was not significantly effective in six cells tested.

Because $k$-receptor effects were often observed in the same cells as $\mu$-receptor effects, the $\mu$-receptor antagonist D-Phe-CysTyr-D-Trp-Orn-Thr-Pen-Thr- $\mathrm{NH}_{2}$ (CTOP) and $\kappa$-receptor antagonist nor-binaltorphimine (nor-BNI) were used to determine whether the observed inhibition of $I_{\mathrm{Ba}^{2}}$ was truly the result of activating two separate populations of receptors. Figure $4 C$ illustrates some typical effects of these selective antagonists. The mean inhibition of $I_{\mathrm{Ba}^{2}+}$ in four neurons exposed to DAMGO was $39.9 \pm 9.8 \%$ and this decreased to $11.2 \pm 4.1 \%$ following exposure to DAMGO in the presence of $300 \mathrm{~nm}$ CTOP. The DAMGO-mediated inhibition recovered fully from this block after around a $7 \mathrm{~min}$ washout (Fig. $4 \mathrm{Ci}$ ). However, in the same series of experiments the $\kappa$-receptor antagonist nor-BNI did not block the DAMGO-mediated inhibition of $I_{\mathrm{Ba}^{2+}}$ significantly (Fig. 4Cii). The mean inhibition of $I_{\mathrm{Ba}^{2+}}$ from four neurons was $45.7 \pm 7.8 \%$ following exposure to DAMGO alone, and this decreased to $41.3 \pm 4.9 \%$ following exposure to DAMGO in combination with $300 \mathrm{~nm}$ nor-BNI. On the other hand, exposure to U-69,593 alone caused a $23.3 \pm 1.8 \%$ inhibition of $I_{\mathrm{Ba}^{2+}}$ and this was inhibited by nor-BNI. U-69,593 produced $2.0 \pm 0.7 \%$ inhibition following nor-BNI $(n=3)$ (Fig. 4Ciii). 


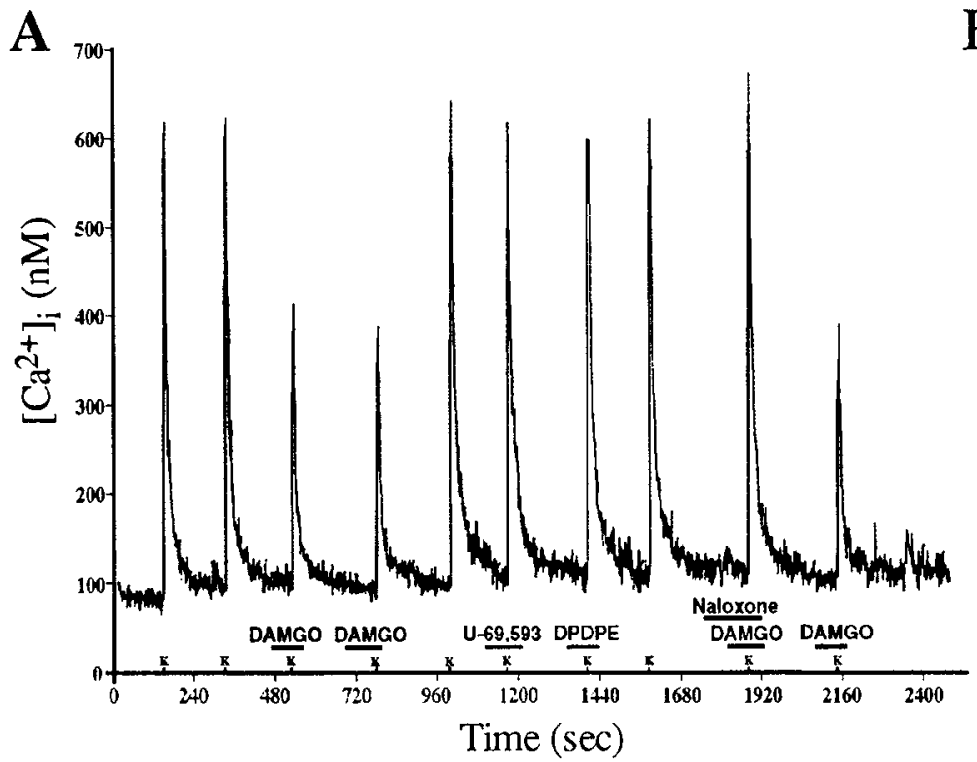

B

Figure 2. Inhibition of depolarization-induced $\left[\mathrm{Ca}^{2}\right]_{i}$ signals by opioids. $A$, This cell was exposed to $50 \mathrm{~K}$ ( $(K)$ for 5 sec using a fast application system. The increase in $\left[\mathrm{Ca}^{2+}\right]_{i}$ was measured using fura-2-based microfluorimetry. DAMGO suppressed the $50 \mathrm{~K}^{+}$-induced increase in $\left[\mathrm{Ca}^{2+}\right]_{i}$ by $40 \%$. This effect was completely reversed by concurrent treatment with $10 \mu \mathrm{M}$ naloxone and recovered again after washout of the antagonist.

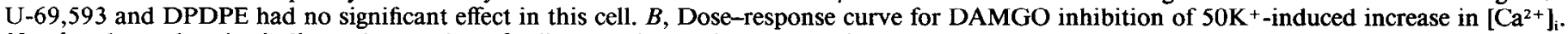
Numbers by each point indicate the number of cells treated at each concentration.

\section{Is a G-protein involved in the coupling between receptor and $\mathrm{Ca}^{2+}$ channel?}

In most cases opioid actions on adenylate cyclase or on ion channels have been reported to be mediated by pertussis toxinsensitive G-proteins (Taussig et al., 1992). We examined the possible involvement of G-proteins by comparing cells dialyzed with GTP and its nonhydrolyzable analog GTP- $\gamma-\mathrm{S}$. When cells were dialyzed with $100 \mu \mathrm{M}$ GTP, $I_{\mathrm{Ba}^{2+}}$ was generally quite stable over time although in some cells a degree of "rundown" was apparent. Furthermore, the inhibition of $I_{\mathrm{Ba}^{2+}}$ by $1 \mu \mathrm{M}$ DAMGO was readily reversible (Fig. $5 A$ ). In contrast, if cells were dialyzed with $100 \mu \mathrm{M}$ GTP- $\gamma-\mathrm{S}, I_{\mathrm{Ba}^{2+}}$ was observed to run down rapidly until it stabilized at a new level. At this point any further inhibition by DAMGO was occluded (Fig. $5 B ; n=6$ ). This result suggests that a G-protein is involved in the coupling between opioid receptor and $\mathrm{Ca}^{2+}$ channel.

\section{Types of $\mathrm{Ca}^{2+}$ channels inhibited by activation of $\mu$-opioid receptor}

We now attempted to find out which types of $\mathrm{Ca}^{2+}$ channels were being inhibited in the NTS neurons. Low-threshold transient (T-type) $\mathrm{Ca}^{2+}$ currents were not observed in these neurons. Multiple types of high-threshold $\mathrm{Ca}^{2+}$ currents were distinguished from each other using pharmacological tools. We found that rat NTS neurons had a $\mathrm{Ba}^{2+}$ current component that was inhibited by dihydropyridines such as nimodipine. The extent of block by nimodipine varied from cell to cell $(10-42 \%$ at 10 $\mu \mathrm{M})$. The mean reduction of $I_{\mathrm{Ba}^{2}+}$ by nimodipine was $24.7 \pm$ $5.5 \%$ in seven neurons. The N-type channel blocker $\omega$-CgTxGVIA blocked a relatively large component of the current $(66.1$ $\pm 2.5 \%$ inhibition at $1 \mu \mathrm{M}, n=7$ ). In addition, a portion of the current was blocked by $\omega$-Aga-IVA $(31.8 \pm 3.5 \%$ at $100 \mathrm{nM}, n$ $=8$ ), which suggests that $\mathrm{P} / \mathrm{Q}$-type $\mathrm{Ca}^{2+}$ channels also existed in the NTS neurons.

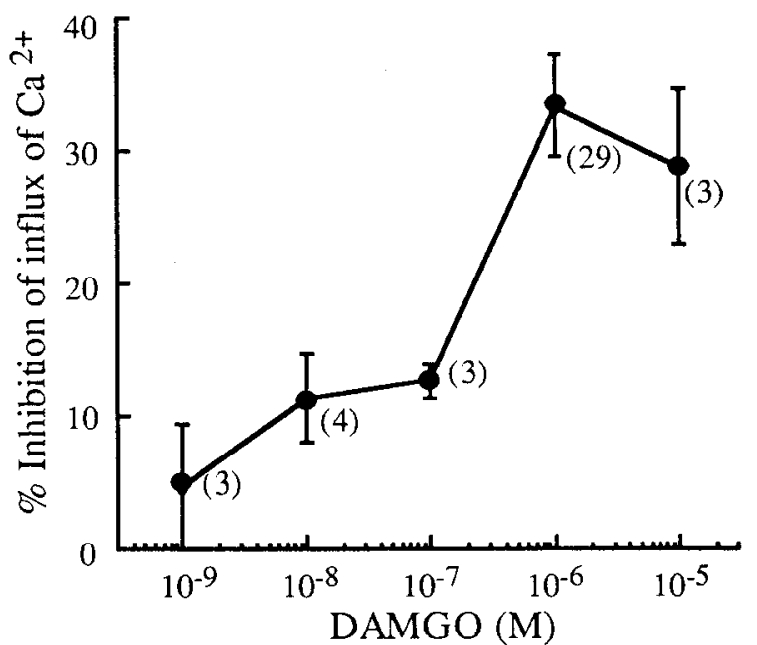

To examine which of these different $\mathrm{Ca}^{2+}$ channels were inhibited following activation of opioid receptors in the NTS neurons, we tested the actions of DAMGO in combination with these $\mathrm{Ca}^{2+}$ channel blockers. The suppression of $I_{\mathrm{Ba}^{2+}}$ by DAMGO was measured before and after application of nimodipine; $1 \mu \mathrm{M}$ DAMGO suppressed $46.7 \pm 2.0 \%$ of $I_{\mathrm{Ba}^{2}+}$ before and 46.1 $\pm 6.8 \%$ after nimodipine block (seven tested cells), suggesting almost none of the current suppressed by DAMGO could be blocked by nimodipine (i.e., was an L-current).

On the other hand, inhibition of $I_{\mathrm{Ba}^{2+}}$ by $\omega$-CgTx-GVIA occluded the major portion of the effect of DAMGO. In six neurons, $1 \mu \mathrm{M}$ DAMGO suppressed $36.7 \pm 8.5 \%$ of $I_{\mathrm{Ba}^{2+}}$ before and $10.9 \pm 3.9 \%$ after $\omega$-CgTx-GVIA block. These results suggest that most of $I_{\mathrm{Ba}^{2}+}$ blocked by DAMGO had the characteristics of an N-current. Schroeder et al. (1991) reported that both $\omega$-CgTx-GVIA-sensitive and $\omega$-CgTx-GVIA-insensitive, highthreshold currents were inhibited by opioids in sensory neurons. We tested whether the actions of DAMGO could also be blocked by P/Q-channel blocker, $\omega$-Aga-IVA. Figure $6 A$ illustrates the effects of DAMGO on a neuron sequentially exposed to all three blockers. The suppression of $I_{\mathrm{Ba}^{2+}}$ by $1 \mu \mathrm{M}$ DAMGO was $45.8 \%$ prior to $\omega$-Aga-IVA (100 nM) application, $27.4 \%$ after $\omega$-AgaIVA block, and was virtually absent following $\omega$-CgTx-GVIA treatment, although the cell still responded to nimodipine at this point. Figure $6 B$ shows pooled results from a series of similar experiments; $1 \mu \mathrm{M}$ DAMGO suppressed $47.3 \pm 2.7 \%$ of $I_{\mathrm{Ba}^{2}+}$ before and $29.6 \pm 4.7 \%$ after $\omega$-Aga-IVA block in six neurons. The DAMGO-mediated $I_{\mathrm{Ba}^{2}+}$ inhibition was blocked by cotreatment with $\omega$-CgTx-GVIA and $\omega$-Aga-IVA $(4.0 \pm 1.5 \%$ inhibition remaining in seven cells). These results suggest that activation of $\mu$-opioid receptors can inhibit $\mathrm{N}$ - and $\mathrm{P} / \mathrm{Q}$-type $\mathrm{Ca}^{2+}$ channels but not L-channels in the NTS neurons.

\section{Discussion}

Voltage-dependent $\mathrm{Ca}^{2+}$ channels are the pathway by which $\mathrm{Ca}^{2+}$ normally enters the nerve terminal to trigger the release 
$\mathbf{A}$

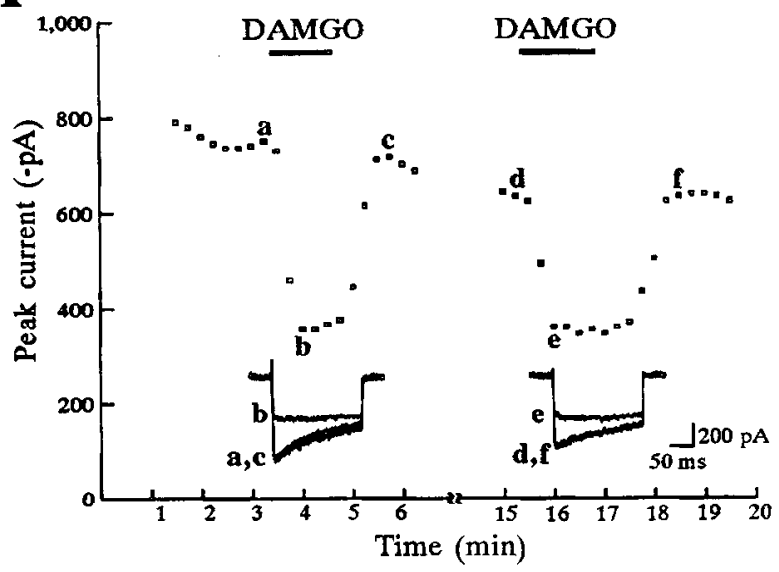

$\mathbf{C}$

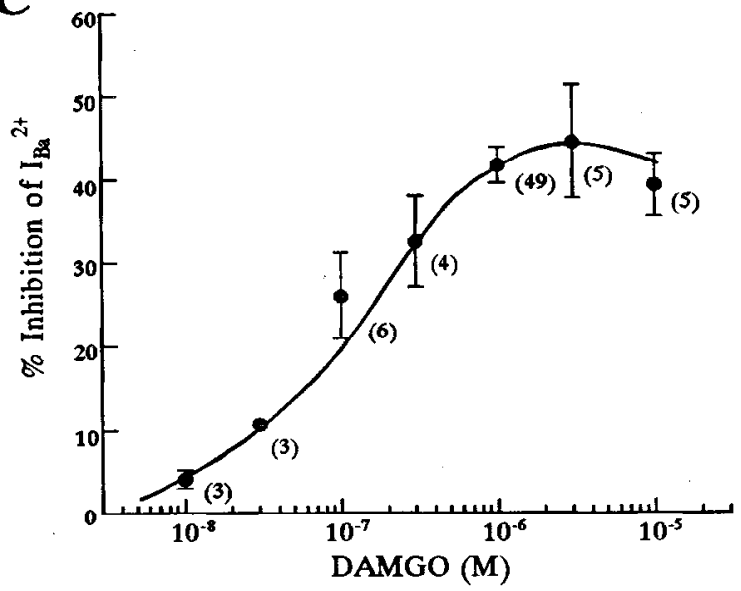

B

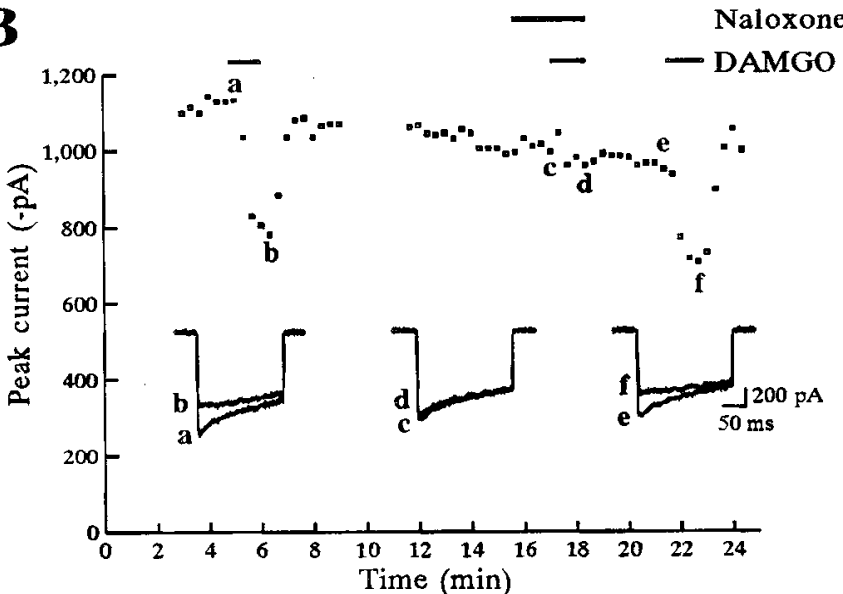

D

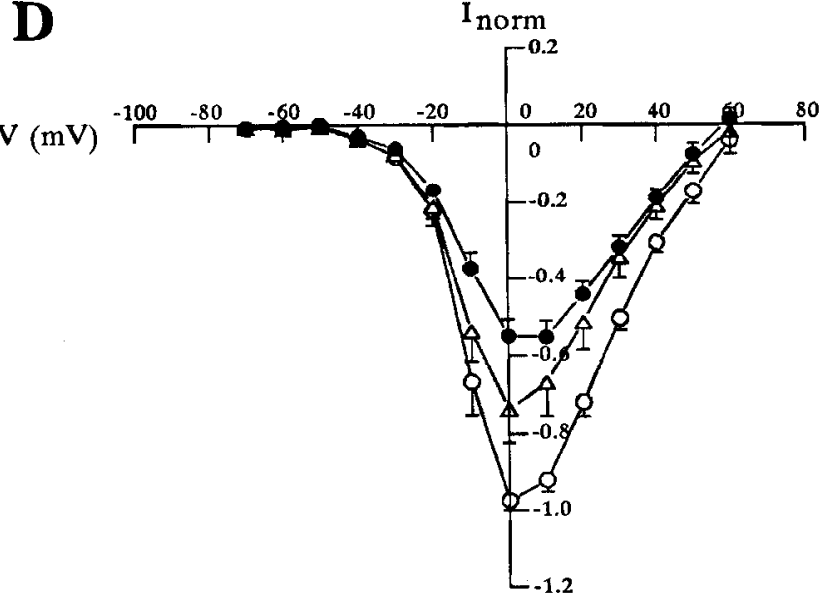

Figure 3. The inhibitory effects of DAMGO on high-threshold $\mathrm{Ca}^{2+}$ channel current in the NTS neurons. A, Time course of peak Ba ${ }^{2+}$ current $\left(I_{\mathrm{Ha}^{+}+}\right)$showing two exposures to DAMGO. Inhibition of $\mathrm{I}_{\mathrm{Ba} 2+}$ was $51 \%$ following the first and $44 \%$ following the second DAMGO application. Inset, Leak-subtracted currents of labeled points from time course of $I_{\mathrm{Ba}^{2+}}$. Currents were evoked every $15 \mathrm{sec}$ by a $200 \mathrm{msec}$ voltage step from -80 mV to $0 \mathrm{mV} . B$, Time course of $I_{\mathrm{Ba}^{2+}}$ during multiple exposures to DAMGO in the presence of naloxone. In this cell $1 \mu \mathrm{M}$ DAMGO inhibited $25 \%$ of $I_{\mathrm{Ba}^{2}+}$ prior to naloxone application. The effect of DAMGO was blocked by $1 \mu \mathrm{M}$ naloxone and recovered from the antagonist block after washout. $C$, Concentration-response relationship for inhibition of $I_{\mathrm{Ba}^{2+}}$ by DAMGO. Numbers by each point indicate the number of cells treated at each concentration. $D$, Current-voltage relationship of normalized $I_{\mathrm{Ba}^{2}+}$ prior to $(O)$, in the presence $(0)$, and after recovery $(\triangle)$ from DAMGO $(1 \mu \mathrm{M})$. Holding potential was $-80 \mathrm{mV}$. Data points represent averages of six experiments for control and drug treatment and five for recovery.

of neurotransmitters. Clearly, regulation of this influx pathway represents a potential mechanism for the modulation of neurotransmission. Indeed there is considerable evidence that this strategy is frequently utilized and that presynaptic receptors can directly couple to $\mathrm{Ca}^{2+}$ channels by G-protein-linked mechanisms (Lipscombe et al., 1989; Miller, 1990; Toth et al., 1993). In some instances modulation of presynaptic $\mathrm{Ca}^{2+}$ channels may be the sole mechanism employed for the production of presynaptic inhibition. For example, we have recently demonstrated that at peripheral neuroeffector junctions presynaptic inhibition produced by neuropeptide $Y$ is due to the inhibition of $\mathrm{Ca}^{2+}$ channels and is not associated with modulation of $\mathrm{K}^{+}$conductances (Toth et al., 1993). Nevertheless it is possible that additional mechanisms may also sometimes be cmployed (Scanziani et al., 1992; Scholz and Miller, 1992; North, 1993a). The observations presented in this report indicate that opioid receptor-mediated inhibition of $\mathrm{Ca}^{2+}$ channels may be a mechanism by which opioids produce presynaptic inhibition in the central as well as the PNS.

Over the last few years it has become clear that central neurons contain a large number of different voltage-dependent $\mathrm{Ca}^{2+}$ channels. At least six genes coding for separate $\alpha$-subunits, which constitute the pore-forming region of the channel, have been identified (Snutch and Reiner, 1992; Miller, 1993; Zhang et al., 1993). As several ancillary subunits (e.g., $\alpha_{2} / \delta, \beta$ ) that are important for channel function also exist, the total number of possible $\mathrm{Ca}^{2+}$ channel complexes is very large indeed (Brust et al., 1993). It has also been shown that these channels differ with respect to their particular neuronal functions; the regulation of transmitter release being a prime example of this. In many peripheral neurons $\mathrm{Ca}^{2+}$ channels with the characteristics of $\mathrm{N}$-channels (probably derived from clone $\alpha_{1 \mathrm{~B}}$ ) seem to play a major role in the control of transmitter release (Toth et al., 1993; Yawo and Chuhma, 1993). In addition, in the CNS, channels of the P/Q-type (probably derived from $\alpha_{1 \mathrm{~A}}$ ) also scem to play an important role in the control of transmitter release (Luebke et al., 1993; Randall et al., 1993; Sather et al., 1993; Takahashi and Momiyama, 1993). If modulation of $\mathrm{Ca}^{2+}$ channels plays an important role in the presynaptic inhibitory effects of opioids then it is important to show that these drugs are capable of 
A

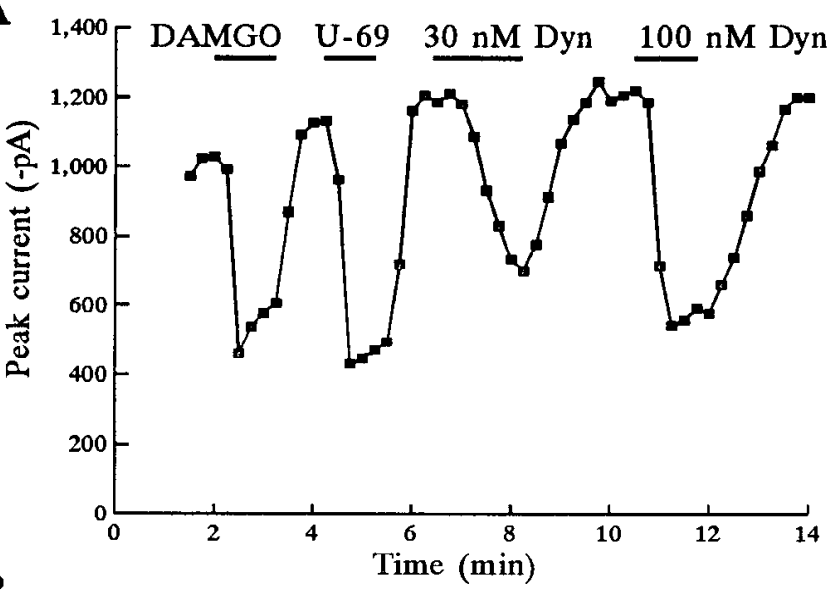

B

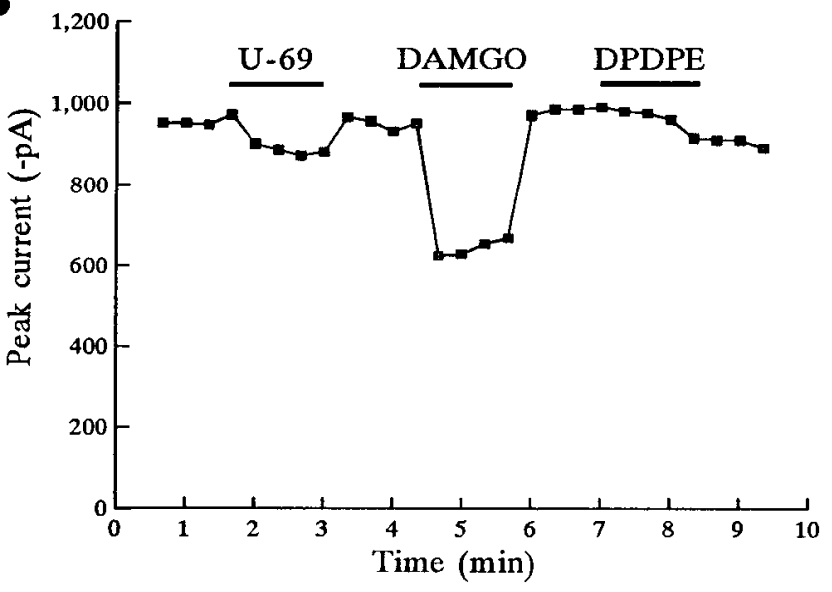

$\mathbf{C}$

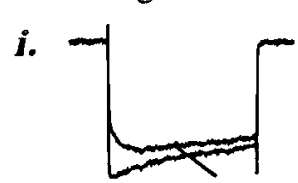

DAMGO

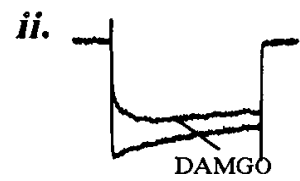

iii. -1

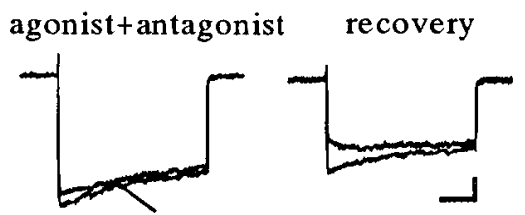

DAMGO+CTOP
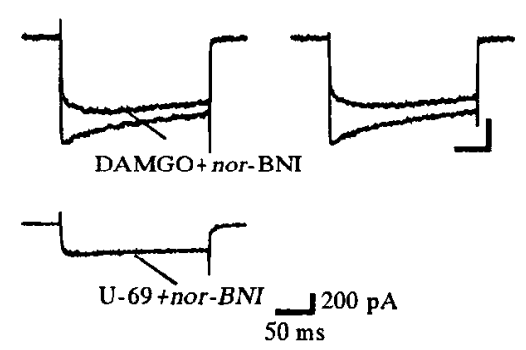

Figure 4. Receptor identification. $A$, Time course of $I_{\mathrm{Ba}^{2+}}$ illustrating responses to different opioid receptor agonists. In this cell, $1 \mu \mathrm{M}$ DAMGO and $1 \mu \mathrm{M}$ U-69,593 (U-69) inhibited $I_{\mathrm{Ba} 2+}$ by $54 \%$ and $62 \%$, respectively; $30 \mathrm{~nm}$ and $100 \mathrm{nM}$ dynorphin $\mathrm{A}(D y n)$ produced $42 \%$ and $56 \%$ inhibition of $I_{\mathrm{Ba}^{2}}$, respectively. $B$, Responses to $\mu$-, $\delta$-, and $k$-selective opioid receptor agonists in another cell. The inhibition of $I_{\mathrm{Ba}^{2+}}$ observed was $9 \%$ and $30 \%$ for U-69 and DAMGO, respectively. DPDPE produced no significant effect. $C$, Selective block of the action of different opioid agonists by corresponding antagonists in different cells. Leaksubtracted $I_{\mathrm{Ba}^{2+}}$ elicited by steps to $0 \mathrm{mV}$ from $-80 \mathrm{mV}$. In $i 1 \mu \mathrm{M}$ DAMGO suppressed $31 \%$ of $I_{\mathrm{Bz}^{2}+}$ before and $10 \%$ after addition of 300 nM CTOP. Full recovery observed together with some current rundown. In $i i$ DAMGO produced the same degree of inhibition alone (43\%) and after addition of $300 \mathrm{nM}$ nor-BNI (39\%). In iii the inhibition of $I_{\mathbf{B a}^{2}}$. was $27 \%$ produced by U-69,593 (U-69) alone and this was completely blocked in the presence of nor-BNI (300 nM).
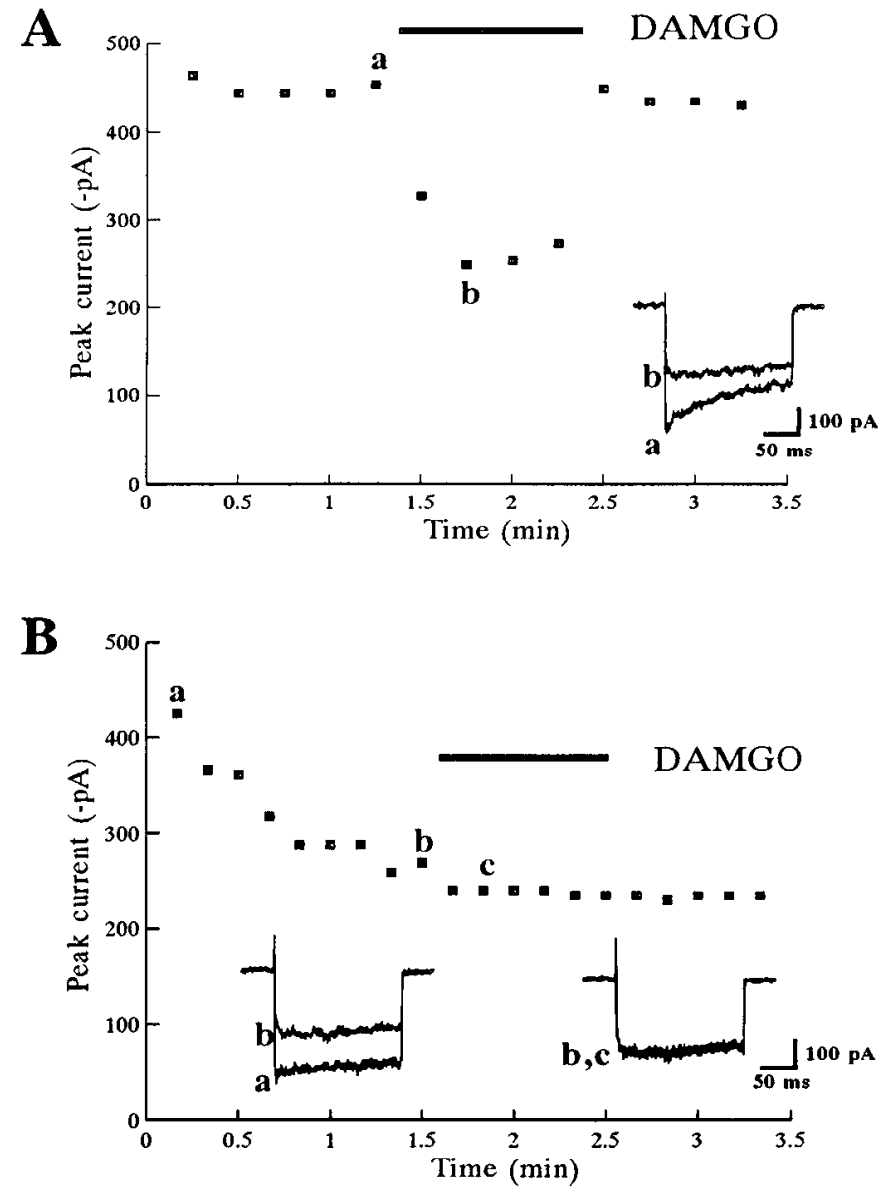

Figure 5. A G-protein couples $\mu$-opioid receptors to $\mathrm{Ca}^{2+}$ channels. $A$, Time course of $I_{\mathrm{Ba}^{2}+}$ illustrating the effect of DAMGO in a cell dialyzed with $100 \mu \mathrm{M}$ GTP. Inset, $I_{\mathrm{Ba}^{2}+}$ at points indicated. $B$, A different cell dialyzed with $100 \mu \mathrm{M}$ GTP- $\gamma-S$. $I_{\mathrm{Ba}^{2}+}$ was measured right after achieving the whole-cell configuration.

modulating the activity of the appropriate $\mathrm{Ca}^{2+}$ channels. In peripheral neurons it has been shown that, depending on the preparation used, $\mu$-, $\kappa$-, and $\delta$-receptors can all inhibit $\mathrm{N}$-type (and sometimes T-type) $\mathrm{Ca}^{2+}$ currents (Gross and MacDonald, 1987; Bean, 1989; Schroeder et al., 1991; Shen and Surprenant, 1991; Taussig et al., 1992). However, no previous data has been available on the CNS. The present results show that the predominant opioid receptor linked to $\mathrm{Ca}^{2+}$ channels in the NTS is the $\mu$-receptor. This is in keeping with anatomical data and our previous studies demonstrating the effects of opioid agonists in NTS slices (Rhim et al., 1993; Thompson et al., 1993). As we have now shown activation of $\mu$-receptors in the NTS produces inhibition of both $\omega$-CgTx-GVIA- and $\omega$-Aga-IVA-sensitive components of the $\mathrm{Ca}^{2+}$ current. The former component is clearly an N-type current. The identity of the latter is more problematic as it has been recently pointed out that $\omega$-Aga-IVA may be able to block more than one component of the $\mathrm{Ca}^{2+}$ current in the brain (Sather et al., 1993; Zhang et al., 1993). At the concentration used in the present studies it seems likely that we are targeting the " $P$ " rather than the " $Q$ " component discussed by Sather and colleagues (1993; see also Mintz and Bean, 1993a). However, as this is not completely clear, we refer to this component as the $\mathrm{P} / \mathrm{Q}$-current. It should also be pointed out that it is also not yet clear what the relative roles of $\mathrm{P}$ - and Q-currents might be in the control of transmitter release and 
A

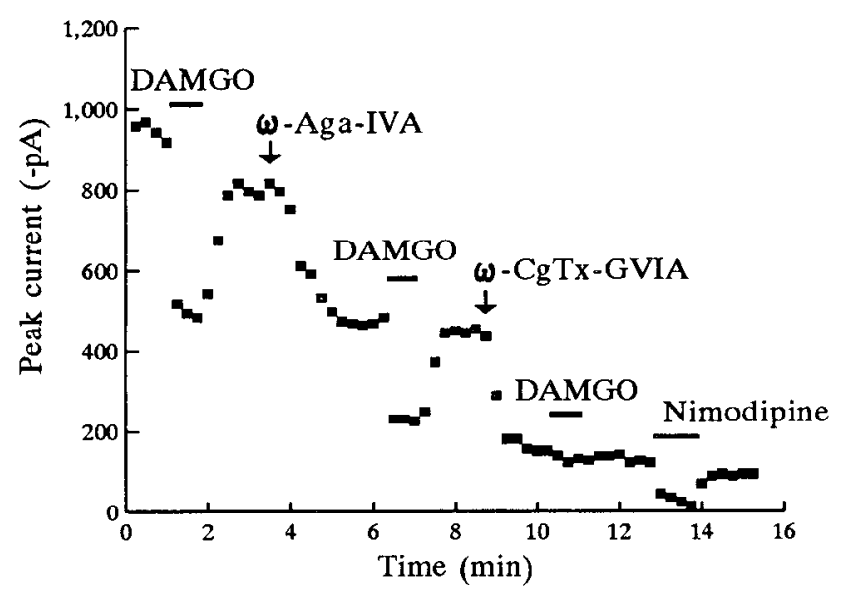

B

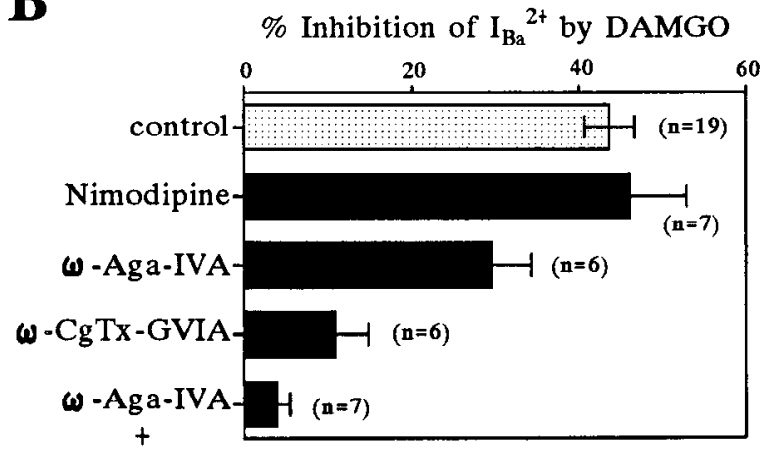

$\omega-\operatorname{CgTx}-$ GVIA

Figure 6. Activation of $\mu$-opioid receptor produces inhibition of both $\omega$-Aga-IVA- and $\omega$-CgTx-GVIA-sensitive $\mathrm{Ca}^{2+}$ channels. $A$, Time course of $I_{\mathrm{Ba}^{2+}}$ illustrating DAMGO effects before and after application of different $\mathrm{Ca}^{2+}$ channel blockers. The suppression of $I_{\mathrm{Ba}^{2+}}$ by $1 \mu \mathrm{M}$ DAMGO was $46 \%$ prior to $\omega$-Aga-IVA (100 nM) application, $27 \%$ after $\omega$-AgaIVA block, and subsequently almost disappeared following $\omega-\mathrm{CgTx}-$ GVIA $(1 \mu \mathrm{M})$ treatment; $100 \mathrm{nM} \omega$-Aga-IVA blocked $39 \%$ of $I_{\mathrm{Ba}^{2+}}$, and $1 \mu \mathrm{M} \omega$-CgTx-GVIA blocked $67 \%$ of the $\omega$-Aga-IVA-insensitive $I_{\mathrm{Ba}^{2+}}$. In addition, $10 \mu \mathrm{M}$ nimodipine completely blocked the $\omega$-Aga-IVA- and $\omega$-CgTx-GVIA-insensitive currents. $B$, Pooled results from $\mathrm{Ca}^{2+}$ channel blocker experiments illustrating the mean inhibition of $I_{\mathrm{Ba}^{2}+}$ by $1 \mu \mathrm{M}$ DAMGO following treatment with different $\mathrm{Ca}^{2+}$ channel blockers. Numbers by each bar indicate the number of cells treated with each drug.

both types have been implicated (Luebke et al., 1993; Randall et al., 1993; Takahashi and Momiyama, 1993). Thus, it may ultimately prove to be the case that both types of currents are modulated by opioids.

The modulation of N-type currents by neurotransmitters in the central as well as the peripheral nervous systems has been quite widely described (Penington et al., 1991; Scholz and Miller, $1991 \mathrm{a}, \mathrm{b}$; Swartz and Bean, 1992; Haws et al., 1993; Mintz and Bean, 1993b; Mogul et al., 1993; Sahara and Westbrook, 1993; Swartz et al., 1993). However, the modulation of $P / Q-$ currents has not yet been extensively demonstrated (Mintz and Bean, 1993b; Mogul et al., 1993; Randall et al., 1993). The present results together with those of Mintz and Bean 1993b indicate that modulation of these $\mathrm{Ca}^{2+}$ channels will have similar characteristics to the well described modulation of N-channels. Thus, it appears that in both cases the inhibitory pathway utilizes a G-protein link and may involve "direct" interaction of the G-protein and some part of the channel without the participation of a diffusible second messenger. This results in a change in the kinetics and voltage dependence of the current. Considering the accumulating data suggesting the importance of $\mathrm{P} / \mathrm{Q}$-channels in the control of transmitter release in the brain it is likely that receptor modulation of these channels will ultimately be widely observed (Luebke et al., 1993; Randall et al., 1993; Takahashi and Momiyama, 1993).

It should also be pointed out that there are other $\mathrm{Ca}^{2+}$ channels in both peripheral and central neurons that are clearly distinct from the N-, P-, and I-types (e.g., the R-currents of cerebellar granule cells; Ellinor et al., 1993; Zhang et al., 1993). These currents can also sometimes be modulated by receptors (Elmslie et al., 1992; Mintz and Bean, 1993b). However, we do not yet know much about them from the molecular point of view. One possibility is that some of them are due to the activity of the recently described $\alpha_{1 \mathrm{E}}$ clone (Ellinor et al., 1993; Soong et al., 1993). Indeed this $\mathrm{Ca}^{2+}$ channel has a structure that is quite closely related to those of $\alpha_{1 \mathrm{~B}}$ and $\alpha_{1 \mathrm{~A}}$, which are probably responsible for $\mathrm{N}$ - and $\mathrm{P} / \mathrm{Q}$-channel activity. This may indicate that it is also susceptible to the same type of G-protein coupled modulation by opioid receptors in some cases. It is also interesting to note that both in the present study and in previous studies of peripheral neurons, activation of opioid receptors never produced modulation of L-currents. It may well be that these currents, which are probably due to the expression of the clones $\alpha_{1 \mathrm{C}}$ and $\alpha_{1 \mathrm{D}}$ (Williams et al., 1992; Tomlinson et al., 1993) are not susceptible to direct $\mathrm{G}$-protein-linked modulation. This would be interesting as these channels differ from $\alpha_{1 \mathrm{~A}}, \alpha_{1 \mathrm{~B}}$ and $\alpha_{1 \mathrm{E}}$ structurally, particularly in the presumed intracellular loop that connects domains 2 and 3 (Snutch and Reiner, 1992). This loop thus may represent a potential site for channel/G-protein interaction.

In addition to modulation by $\mu$-receptors we also noted that the $\mathrm{Ca}^{2+}$ currents in some cells were also inhibited by $\kappa$-receptor agonists. This effect was seen less consistently than the effects of $\mu$-receptor activation. Interestingly, the $\kappa$-effects were often observed on the same cells as the $\mu$-effects. Thus some of these neurons may be susceptible to the effects of more than one endogenous opioid. We never observed effects of $\delta$-opioid agonists consistent with our previous observations in the NTS slice (Rhim et al. 1993). The relative paucity of $\kappa$ - and $\delta$-effects may have more to do with the fact that $\delta$ - and $\kappa$-receptors are less well represented in this nucleus (Xia and Haddad, 1991) rather than any inability of these receptors to influence $\mathrm{Ca}^{2+}$ channels. Thus in peripheral systems both $\delta$ - and $\kappa$-receptors have been shown to produce robust inhibition of $\mathrm{N}$-currents (Gross and MacDonald, 1987; Bean, 1989; Schroeder et al., 1991; Shen and Surprenant, 1991; Taussig et al., 1992). Nevertheless, results showing coupling of $\delta$-receptors to $\mathrm{Ca}^{2+}$ channels in the brain are still lacking.

What do our results tell us about the regulation of the NTS by opioids? Receptor modulation of $\mathrm{Ca}^{2+}$ influx into the cell soma may have a variety of effects including the regulation of a variety of $\mathrm{Ca}^{2+}$-dependent ion channels. Effects on gene expression and metabolism are also possible. However, it is also likely that the effects we have demonstrated may also occur on the terminals of the same neurons. Some of these may be interneurons and others may be efferents projecting to various parts of the CNS including parts of the pons, the medulla, the spinal cord, and the hypothalamus (Van Giersbergen et al., 1992). If this is true then this would represent a mechanism by which opioids could regulate transmitter release from these cells. 


\section{References}

Bean BP (1989) Neurotransmitter inhibition of neuronal calcium currents by changes in channel voltage dependence. Nature 340:153156.

Brust PF, Simerson S, McCue AF, Deal CR, Schoonmaker S, Williams ME, Veliçelebi G, Johnson EC, Harpold MM, Ellis SB (1993) Human neuronal voltage-dependent calcium channels: studies on subunit structure and role in channel assembly. Neuropharmacology 32: 1089-1102.

Capogna M, Gähwiler BH, Thompson SM (1993) Mechanism of $\mu$-opioid receptor-mediated presynaptic inhibition in the rat hippocampus in vitro. J Physiol (Lond) 470:539-558.

Ellinor PT, Zhang JF, Randall AF, Zhou M, Schwarz TL, Tsien RW, Horne WA (1993) Functional expression of a rapidly inactivating neuronal calcium channel. Nature 363:455-458.

Elmslie KS, Kammermeier PJ, Jones SW (1992) Calcium current modulation in frog sympathetic neurons: L-current is relatively insensitive to neurotransmitters. J Physiol (Lond) 456:107-123.

Gross RA, MacDonald RL (1987) Dynorphin A selectively reduces a large transient (N-type) calcium current of mouse dorsal root ganglion neurons in cell culture. Proc Natl Acad Sci USA 84:5469-5473.

Hamill OP, Marty A, Neher E, Sakmann B, Sigworth FJ (1981) Improved patch-clamp techniques for high resolution current recording from cells and cell-free membrane patches. Pfluegers Arch 391:85100.

Haws CM, Slesinger PA, Lansman JB (1993) Dihydropyridine- and $\omega$-conotoxin-sensitive $\mathrm{Ca}^{2+}$ currents in cerebellar neurons: persistent block of L-type channels by a pertussis toxin-sensitive G-protein. J Neurosci 13:1148-1156.

Herbert H, Moga MM, Saper CB (1990) Connections of the parabrachial nucleus with the nucleus of the solitary tract and the medullary reticular formation in the rat. J Comp Neurol 293:540-580.

Herrington J, Lingle CJ (1992) Kinetic and pharmacological properties of low voltage-activated $\mathrm{Ca}^{2+}$ current in rat clonal $\left(\mathrm{GH}_{3}\right)$ pituitary cells. J Neurophysiol 68:213-232.

Kennedy C, Henderson G (1991) $\mu$-Opioid receptor inhibition of calcium current: development of homologous tolerance in single SHSY5Y cells after chronic exposure to morphine in vitro. J Pharmacol Exp Ther 40:1000-1005.

Lipscombe D, Kongsamut S, Tsien RW (1989) $\alpha$-Adrenergic inhibition of sympathetic neurotransmitter release mediated by modulation of N-type calcium channel gating. Nature 340:639-642.

Luebke JI, Dunlap K, Turner TJ (1993) Multiple $\mathrm{Ca}^{2+}$ channel types control glutamatergic synaptic transmission in the hippocampus. Neuron 11:895-902.

Miller RJ (1990) Receptor-mediated regulation of calcium channels and neurotransmitter release. FASEB J 4:3291-3299.

Miller RJ (1993) Ca channels: a tale of two toxins. Curr Biol 3:481483.

Mintz IM, Bean BP (1993a) Block of calcium channels in rat neurons by synthetic $\omega$-Aga-IVA. Neuropharmacology 32:1161-1169.

Mintz IM, Bean BP (1993b) GABA receptor inhihition of P-type $\mathrm{Ca}^{2+}$ channels in central neurons. Neuron 10:889-898.

Mogul DJ, Adams ME, Fox AP (1993) Differential activation of adenosine receptors decreases $\mathrm{N}$-type but potentiates $\mathrm{P}$-type $\mathrm{Ca}^{2+}$ current in hippocampal CA3 neurons. Neuron 10:327-334.

Nakagawa T, Shirasaki T, Wakamori M, Fukuda A, Akaike N (1990) Excitatory amino acid response in isolated nucleus tractus solitarii neurons of the rat. Neurosci Res 8:114-123.

North RA (1993a) Opioid actions on membrane ion channels. Handbk Exp Physiol 104:773-796.

North RA (1993b) Presynaptic actions of opioids. In: Presynaptic receptors in the mammalian brain (Dunwiddie TV, Lovinger DM, eds), pp 71-86. Boston: Birkhäuser.

Penington NJ, Kelly JS, Fox AP (1991) A study of the mechanism of $\mathrm{Ca}^{2+}$ current inhibition produced by serotonin in rat dorsal raphe neurons. J Neurosci 11:3594-3609.

Randall AD, Wheeler DB, Tsien RW (1993) Modulation of Q-type $\mathrm{Ca}^{2+}$ channels and Q-type $\mathrm{Ca}^{2+}$ channel-mediated synaptic transmission by metabotropic and other G-protein linked receptors. Funct Neurol 8:44.

Reisine T, Bell GI (1993) Molecular biology of opioid receptors. Trends Neurosci 16:506-510.

Rekling JC (1993) Effects of Met-enkephalin on GABAergic sponta- neous miniature IPSPs in organotypic slice cultures of the rat hippocampus. J Neurosci 13:1954-1964.

Rhim H, Glaum SR, Miller RJ (1993) Selective opioid agonists modulate afferent transmission in the rat nucleus tractus solitarius. J Pharmacol Exp Ther 264:795-800.

Sahara Y, Westbrook GL (1993) Modulation of calcium currents by a metabotropic glutamate receptor involves fast and slow kinetic components in cultured hippocampal neurons. J Neurosci 13:30413050.

Sather WA, Tanabe T, Zhang JF, Mori Y, Adams ME, Tsien RW (1993) Distinctive biophysical and pharmacological properties of class $A(B I)$ calcium channel $\alpha_{1}$ subunits. Neuron 11:291-303.

Scanziani M, Capogna M, Gähwiler BH, Thompson SM (1992) Presynaptic inhibition of miniature excitatory synaptic currents by baclofen and adenosine in the hippocampus. Neuron 9:919-927.

Scholz KP, Miller RJ (1991a) Analysis of adenosine actions on $\mathrm{Ca}^{2+}$ currents and synaptic transmission in cultured rat hippocampal pyramidal neurons. J Physiol (Lond) 435:373-393.

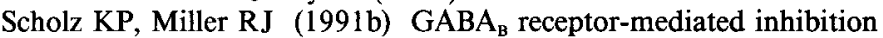
of $\mathrm{Ca}^{2+}$ currents and synaptic transmission in cultured rat hippocampal neurons. J Physiol (Lond) 444:669-686.

Scholz KP, Miller RJ (1992) Inhibition of quantal transmitter release in the absence of calcium influx by a G-protein linked adenosine receptor at hippocampal synapses. Neuron 8:1139-1150.

Schroeder JE, Fischbach PS, Zheng D, McCleskey EW (1991) Activation of $\mu$ opioid receptors inhibits transient high- and low-threshold $\mathrm{Ca}^{2+}$ currents but spares a sustained current. Neuron 6:13-20.

Seward E, Hammond C, Henderson G (1991) $\mu$-Opioid receptor mediated inhibition of N-type calcium current. Proc R Soc Lond [Biol] 244:129-135.

Shen KZ, Surprenant A (1991) Noradrenaline, somatostatin and opioids inhibit activity of single HVA/N-type calcium channels in excised neuronal membranes. Pfluegers Arch 418:614-616.

Snutch TP, Reiner PB (1992) $\mathrm{Ca}^{2+}$ channels: diversity of form and function. Curr Opin Neurobiol 2:247-253.

Soong TW, Stea A, Hodson CD, Dubel SJ, Vincent SR, Snutch TP (1993) Structure and functional expression of a member of the low voltage-activated calcium channel family. Science 260:1133-1136.

Swartz KJ, Bean RP (1992) Inhibition of calcium channels in rat CA3 pyramidal neurons by a metabotropic glutamate receptor. J Neurosci 12:4358-4371.

Swartz KJ, Merritt A, Bean BP, Lovinger DM (1993) Protein kinase $\mathrm{C}$ modulates glutamate receptor inhibition of $\mathrm{Ca}^{2+}$ channels and synaptic transmission. Nature 361:165-168.

Takahashi T, Momiyama A (1993) Different types of calcium channels mediate central synaptic transmission. Nature 366:156-158.

Taussig R, Sanchez S, Rifo M, Gilman AG, Belardetti F (1992) Inhibition of the $\omega$-conotoxin-sensitive calcium current by distinct $G$ proteins. Neuron 8:799-809.

Thompson RC, Mansour A, Akil H, Watson SJ (1993) Cloning and pharmacological characterization of a rat $\mu$ opioid receptor. Neuron 11:903-913.

Tomlinson WJ, Stea A, Bourinet E, Charnet P, Nargeot J, Snutch TP (1993) Functional properties of a neuronal class C L-type calcium channel. Neuropharmacology 32:1117-1126.

Toth PT, Bindokas VP, Bleakman D, Colmers WF, Miller RJ (1993) Mechanism of presynaptic inhibition by neuropeptide $\mathrm{Y}$ at sympathetic nerve terminals. Nature 364:635-639.

Van Giersbergen PLM, Palkovits M, De Jong W (1992) Involvement of neurotransmitters in the nucleus tractus solitarii in cardiovascular regulation. Physiol Rev 72:789-824.

Williams ME, Feldman DH, McCue AF, Brenner R, Veliçelebi G, Ellis SB, Harpold MM (1992) Structure and functional expression of $\alpha_{1}, \alpha_{2}$ and $\beta$ subunits of a novel neuronal calcium channel subtype. Neuron 8:71-84.

Xia Y, Haddad GG (1991) Ontogeny and distribution of opioid receptors in the rat brainstem. Brain Res 549:181-193.

Yawo H, Chuhma N (1993) Preferential inhibition of $\omega$-conotoxinsensitive presynaptic $\mathrm{Ca}^{2+}$ channels by adenosine autoreceptors. Nature 365:256-258.

Zhang JF, Randall AD, Ellinor PT, Horne WA, Sather WA, Tanabe T, Schwarz TL, Tsien RW (1993) Distinctive pharmacology and kinetics of cloned neuronal $\mathrm{Ca}^{2+}$ channels and their possible counterparts in mammalian CNS neurons. Neuropharmacology 32:10751088 